\title{
The Unrealized Potential of National Human Rights Institutions in Business and Human Rights Regulation: Conditions for Effective Engagement and Proposal for Reform
}

\section{René Wolfsteller ${ }^{1}$ (D)}

Accepted: 5 September 2021 /Published online: 10 November 2021

(c) The Author(s) 2021, corrected publication 2021

\begin{abstract}
While National Human Rights Institutions (NHRIs) are widely regarded as particularly promising tools in the emerging transnational regime for the regulation of business and human rights, we still know little about their potential and actual contribution to this field. This article bridges the gap between business and human rights research and NHRI scholarship, proceeding in three steps: Firstly, I analyze the structural conditions for NHRIs to tackle business-related human rights abuses effectively, focusing on the key conditions of legitimacy and competences. Secondly, I examine the envisaged role and functions of NHRIs in business and human rights regulation according to the Paris Principles and the UN Guiding Principles. Thirdly, I reconstruct and critically assess NHRIs' mandates and powers to address corporate human rights abuse, based on the analysis of surveys and reports. I argue that there is a significant mismatch between the essential structural conditions for effective NHRI engagement with business and human rights, the expected contribution of NHRIs to the prevention and remedy of corporate human rights abuses, and the limitations of their mandates and powers in practice. To overcome that misalignment and unlock NHRIs' full potential, this article proposes a reform of the Paris Principles which would provide these institutions with a robust source of international legitimacy and increase the pressure on state governments to extend their powers.
\end{abstract}

Keywords Business and human rights · National Human Rights Institutions · UN Guiding Principles $\cdot$ Paris principles $\cdot$ Access to remedy $\cdot$ Non-judicial grievance mechanism

René Wolfsteller

Rene.wolfsteller@politik.uni-halle.de

1 Department of Political Science, Martin-Luther-Universität Halle-Wittenberg,

06099 Halle (Saale), Germany 


\section{Introduction}

National Human Rights Institutions (NHRIs), such as human rights commissions and ombudsmen, have over the past 20 years evolved as important actors of the international human rights system. Promoted by the United Nations (UN) through resolutions ${ }^{1}$ and treaty mechanisms ${ }^{2}$ as independent state bodies with a mandate to promote and protect human rights, NHRIs have been established in more than 120 countries, in democracies and authoritarian states alike, and in every region of the world (Linos and Pegram 2017: 679). ${ }^{3}$ NHRIs occupy a "unique position" (Smith 2006: 904) in the global governance of human rights, with the potential to act as an integrating link between the international human rights system and the national sphere, as well as between state and non-state actors (Mertus 2009; Goodman and Pegram 2012).

While NHRIs have traditionally concentrated their regulatory efforts on state actors as the typical rights abusers (Cardenas 2014: 10), they are increasingly addressing rights violations by corporate actors and have been actively involved in the creation of new international norms for the regulation of business and human rights; in particular, the UN Guiding Principles on Business and Human Rights (UNGPs) endorsed by the UN Human Rights Council in 2011 (Brodie 2012; Haász 2013). ${ }^{4}$ Consequently, NHRIs are widely regarded as particularly promising tools for advancing the implementation of the UNGPs and for holding corporate actors accountable for human rights abuses (e.g., ICC 2010; Schuller and Utlu 2014; McGrath 2019; Methven O'Brien and Ford 2019; Jägers 2020). The Special Representative of the UN Secretary-General (SRSG), John Ruggie, and the UN Human Rights Council have specifically emphasized the capacity of NHRIs to act as nonjudicial remedy mechanisms for victims of corporate human rights abuses. ${ }^{5}$

But although there is a fast-growing body of literature on business and human rights and on the implementation of the UNGPs (e.g., Mares 2012; Deva and Bilchitz 2013; Bernaz 2017; Rodríguez-Garavito 2017), there is relatively little knowledge by comparison of the structural conditions for NHRIs to be able to meet these diverse expectations, as NHRI scholarship has been slow to engage with the field of business and human rights (for notable exceptions, see Brodie 2012; Haász 2013; Reif 2017).

\footnotetext{
1 E.g., United Nations General Assembly Resolutions A/RES/48/134, 4 March 1994; A/RES/66/169, 11 April 2012; A/RES/70/163, 10 February 2016.

2 Optional Protocol to the Convention against Torture and Other Cruel, Inhuman or Degrading Treatment or Punishment (OPCAT) (2002), part IV, art. 17 to 20; Convention on the Rights of Persons with Disabilities (CRPD) (2006), art. 33.

3 For a list of all NHRIs registered with the Global Alliance of National Human Rights Institutions (GANHRI), see GANHRI, Chart of the Status of National Institutions - Accreditation status as of 20 January 2021, available at: https://nhri.ohchr.org/EN/AboutUs/GANHRIAccreditation/Documents/Status\%20Accreditation\%20Chart\%20as\%20of\%2020\%2001\%202021.pdf (accessed 10 February 2021).

${ }^{4}$ United Nations Human Rights Council (UNHRC), A/HRC/RES/17/4, 6 July 2011, para. 1.

5 UNHRC A/HRC/8/5, 7 April 2008, para. 97; A/HRC/17/31, 21 March 2011, Annex para. 27; A/HRC/ RES/38/13, 18 July 2018, preamble and para. 11.
} 
This article contributes to closing that gap by identifying and analyzing the structural conditions under which NHRIs can effectively tackle and help prevent business-related human rights abuse and by examining to what extent these conditions are met by the current regime for the governance of NHRIs. It bridges the divide between two bodies of literature by applying insights from NHRI scholarship on the conditions for organizational effectiveness to the specific contribution of NHRIs to business and human rights regulation. Moreover, the article seeks to contribute to policy debates about the effective prevention and remedy of corporate human rights abuse by highlighting the structural obstacles that hinder many NHRIs from enhancing private sector compliance with human rights standards and by pointing out ways of how to better align the different strands of the international human rights system so that, in the longer term, more NHRIs can realize their full potential in the regulation of business and human rights.

I begin by making the case for conceptualizing NHRI effectiveness in terms of the institution's impact, before analyzing the conditions for NHRI effectiveness in the specific issue-area of business and human rights. I argue that the legitimacy and competences to promote and protect human rights in both the public and private sectors constitute the two most fundamental conditions for effective NHRI engagement with business-related human rights abuse. Legitimacy is conceived here as the formalized mandate of NHRIs according to national and international law, whereas by competences I refer to the institution's specific, legally codified powers to put that mandate into practice. ${ }^{6}$ Next, I critically examine the mandate and powers of NHRIs to tackle corporate human rights abuse as prescribed by the Paris Principles and their envisaged role in the UN Guiding Principles, as the two most authoritative international standards for the transnational governance of NHRIs and of business and human rights, respectively. This analysis is contrasted with an assessment of NHRIs' mandates and powers in practice as reconstructed from surveys and reports. Finally, I propose to overcome the structural barriers inhibiting more effective NHRI engagement with corporate human rights abuse through a reform of the Paris Principles so as to provide NHRIs with a more robust source of international legitimacy and to pressurize state governments into extending their mandates and powers to the private sector.

\section{What makes NHRIs effective?}

Although NHRIs have traditionally focused on improving state compliance with national and international human rights standards, they are increasingly engaging in activities to promote and protect human rights in the private sector. Indeed, the growing number of examples of "good practice" illustrates the significant potential

\footnotetext{
${ }^{6}$ This legal definition of legitimacy differs from the conception of "public" or "perceived" legitimacy which refers to the belief and recognition by a given audience that an institution's power is exercised appropriately (although this perception is likely to be influenced by its legally formalized mandate; Smith 2006: 906).
} 
of NHRIs to tackle corporate human rights abuse and operationalize the UNGPs, for instance, by providing advice and guidance to both state and non-state actors, monitoring laws and policies, launching inquiries and investigations, resolving complaints or remedying business-related human rights abuse (for overviews of NHRI practice, see Haász 2013; McGrath 2019; Cantú Rivera 2020). So far, however, evidence of NHRI 'good practice' in the area of business and human rights is scattered and unsystematic, making it difficult to draw generalizable conclusions for the conditions of their effectiveness. Moreover, while the broad range of activities and the diversity of institutional mandates, powers, and local contexts present well-known problems for NHRI scholars, analyzing the conditions for effective engagement with corporate human rights abuse raises various additional challenges. These include vague responsibilities and legal obligations of business firms, especially of transnational corporations (TNCs); weak accountability mechanisms; the difficulty to formulate a positive business case for greater human rights compliance in many industries; and a reluctance to cooperate with state actors and regulatory bodies (e.g., see Ruggie 2013; Bernaz 2017; Götzmann and Lorion 2020). This section seeks to address these issues: first, by conceptualizing NHRI effectiveness in terms of the institution's impact and, second, by examining the structural conditions that enable NHRIs to effectively contribute to the promotion and protection of human rights by business actors.

\section{Conceptualizing NHRI Effectiveness as Impact}

With the proliferation of NHRIs since the 1990s, the question of their effectiveness in the promotion and protection of human rights has gained increasing attention by scholars and activists alike. NHRIs are inherently paradoxical organizations: They are established and funded through the state yet are expected to function as independent institutions monitoring, preventing and regulating rights abuses, mostly by actors associated with the state (Brodie 2015: 1217). The tension arising from their positionality between government and civil society, and the inherent tendency to create political opposition through their work, renders NHRIs particularly vulnerable to manipulation by the government (Mertus 2009: 3). In light of that structural vulnerability, scholars have noted that "[w]hat is surprising is that many of them have functioned, nonetheless" (Rosenblum 2012: 322). But what is an effective, a "functioning," NHRI?

As the aim of this article is to analyze the conditions which enhance the capability of NHRIs to contribute to improving respect for, and compliance with, human rights norms and standards in the private sector, it makes sense to conceptualize organizational effectiveness first and foremost in terms of the institution's impact. An impactbased approach measures the organizational effectiveness of an NHRI according to the extent to which it has "positively improved and alleviated the human rights situation of individuals and groups in a given society" (Linos and Pegram 2017: 644; see also Mertus 2012: 83-87). This may involve assessing whether an NHRI has directly contributed to the reduction, ending, or remedy of concrete instances of human rights abuse through investigating and resolving complaints or by lobbying 
or pressurizing state and non-state actors into compliance with national and international human rights norms through legal or policy reforms. Although this is often more difficult to assess, it may also involve the evaluation of an NHRI's contribution to cultural change through the provision of training and education for key actors, through the 'naming and shaming' of perpetrators, and by engaging in promotional and awareness raising activities.

The impact-based approach to organizational effectiveness has the significant advantage of prioritizing the core purpose of NHRIs: to improve respect for, and the protection of, human rights norms and standards in one form or another, for " $[\mathrm{t}] \mathrm{here}$ is clearly little point establishing a NHRI unless it can effect some positive change" (Murray 2007: 210). Although an evaluation of NHRI performance according to the fulfillment of its specific mandate may be the most straight-forward and perhaps the more realistic approach, it also represents a rather minimalist benchmark because it does not allow for evaluating an institution's actual contribution to human rights change, nor for criticizing its limited focus or its operation on a sub-standard mandate (Mertus 2012: 80-82). Similarly, an approach assessing an NHRI solely according to its ability to address the gravest human rights violations in a country and the needs of its most vulnerable groups (e.g., Rosenblum 2012) has only limited regard to the overall change an NHRI has brought while potentially setting the bar for effective performance too high if the most critical human rights issues fall outside the body's sphere of influence. While it is important to consider its structural constraints and the needs of the most vulnerable groups in society, prioritizing the impact of an institution is more suitable for analyzing the conditions under which NHRIs can effectively contribute to improving respect for, and protection of, human rights by corporate actors. But which factors influence the effectiveness of NHRIs and, more specifically, their ability to contribute to the reduction, prevention, or remedy of human rights abuses by corporate actors?

\section{Conditions for Effective NHRI Engagement with Business and Human Rights}

Scholars agree that there is no single factor which alone determines the effectiveness of an institution, but that its impact and performance is influenced by a range of factors: every NHRI "operates within an environment of constraints and opportunities, some of which the [institution] has greater capacity to influence than others" (Harvey and Spencer 2012: 1685; see also Kumar 2003; Murray 2007; Linos and Pegram 2017). Factors that are largely outside of an NHRI's control, but which have significant impact on its performance concern the political, economic and societal environment in which an NHRI is established and in which it operates. These contextual factors comprise the potential for violence in a country, the regime type, ${ }^{7}$ the

\footnotetext{
7 This is not to say that NHRIs in liberal democracies are necessarily more effective. Indeed, many western liberal democracies conceptualize human rights as a product that is primarily 'for export' to other countries and tend to contest their (stronger) domestic institutionalization. For the detailed analysis of an exemplary case of that western hubris, see Wolfsteller 2020 on the failed translation of international human rights norms in the United Kingdom.
} 
existence or absence of a functioning judicial system and of a strong civil society (see Wolfsteller and Gregg 2017; Wolfsteller 2017), but also the structural conditions of the institution's operation, such as the NHRI's mandate and powers, funding, independence, and accountability arrangements (Mertus 2009; 2012). Factors that are largely within the body's control include efficient management and leadership, staff expertise, a clear strategic plan and vision, as well as accessible and transparent communication with stakeholders (Harvey and Spencer 2012: 1685; Murray 2007: 207, 214-219).

While all of these factors are important for the effective operation of NHRIs in general, two of them are critical for an institution's ability to engage with corporate human rights abuse in a meaningful way: legitimacy, defined here as the mandate of an NHRI according to national and international law, and competences, understood as the body's specific, legally codified powers to put its mandate into practice. In the following section, I argue that (1) a broad mandate and (2) the combination of strong promotional and investigative powers, both of which extend to state and non-state actors, constitute essential structural conditions for NHRIs to make an effective contribution to the specific issue-area of corporate human rights abuse.

\section{Mandate}

The mandate of an NHRI defines the body's legal status and relationship to other actors and institutions, such as the government, parliament, the judicial system, public administration, and civil society. Scholars agree that a legally formalized mandate-ideally, through the constitution or a legislative act-ensures a degree of stability and autonomy over time, rendering the institution less vulnerable to attempts to abolish it, to change its structure or powers, or to otherwise interfere with its effective operation (Smith 2006: 913-914; Murray 2007: 194-195; Linos and Pegram 2017: 633). But the mandate also defines the boundaries of the institution's jurisdiction, its functions, and powers. It thereby critically shapes the ability of the organization to engage with corporate human rights abuse, in four specific ways.

First, the mandate determines whether an NHRI is allowed to investigate, monitor, and report on, human rights violations committed by any actor or only those caused by actors associated with the state (which is often the case in NHRIs with complaints handling powers, see Reif 2017). It thus prescribes which types of actors the NHRI can regulate and collaborate with, for instance, in providing advice and training or investigating a complaint. In order to realize the full potential of NHRIs in tackling corporate human rights abuse, however, their mandate needs to go beyond state-owned enterprises and allow them to engage with state as well as nonstate actors, and to monitor and report on any incident of human rights abuse, irrespective of the perpetrator.

Second, by defining the geographical boundaries of an NHRI's jurisdiction, the statutory mandate regulates the extent to which an NHRI is legally authorized to operate inside and outside national borders. It thereby enables or disables the institution to participate in transnational networks or mechanisms (e.g., the UN treaty monitoring system), but also to collaborate with organizations abroad, such as other NHRIs, in monitoring and capacity-building activities or in the coordination of 
transnational investigations. The geographical boundaries of an NHRI's mandate are of particular relevance to the field of business and human rights because the rise of multinational corporations, and the global diffusion of supply chains has created responsibility and accountability gaps which are difficult to close for nationally oriented human rights protection systems - often due to a lack of state capacity and/ or willingness to regulate the private sector. If equipped with an adequate statutory mandate for transnational collaboration, NHRIs as a network can play an important role in monitoring business-related human rights abuse across national borders and in holding corporate actors accountable through the naming and shaming of perpetrators who have otherwise no sanctions to fear in their home states (Schuller and Utlu 2014: 8, 24-25; McGrath 2019: 84).

Third, the mandate defines the range of rights norms and standards an NHRI is allowed to promote and protect. Usually, this includes the rights recognized in the constitution and national law, but it may also extend to the norms set out in the international human rights instruments to which the state is party. For the effective promotion and protection of human rights in the private sector, however, it is of vital importance that the rights focus of an NHRI is as broad as possible; in particular, that its mandate covers not only civil and political rights but also economic, social, and cultural rights (Murray 2007: 201; Kumar 2006: 779). This is because incidents of corporate human rights abuse often involve the infringement of economic and social rights, such as the right to freedom from slavery and forced labour, the right to fair wages, to safe and healthy working conditions, to form and join trade unions, and to enjoy the highest attainable standard of physical and mental health. ${ }^{8}$

Fourth, the mandate defines the functions and powers of an NHRI. It prescribes whether an institution is vested with investigative (or protective) powers ${ }^{9}$ to perform a regulatory role or with promotive powers to operate as an agent of cultural change or-as is often the case-with a combination of both. Yet irrespective of how the balance is struck between different types of powers, their formal definition and authorization by statute make it more likely that actors cooperate and comply with the NHRI's requests and recommendations. If its powers are not legally defined or lack clarity, actors are unlikely to accept the use of the powers invoked as legitimate and will refuse to cooperate, especially if the NHRI is operating in a hostile environment or if the targeted actors have rather weak obligations to respect and comply with human rights, such as business firms.

\section{Powers}

Apart from the statutory remit, the effectiveness of NHRIs and especially their impact in the area of corporate human rights abuse critically depends on the powers available to the body. NHRI scholars suggest that "NHRIs should have both

\footnotetext{
${ }^{8}$ International Covenant on Economic, Social and Cultural Rights (ICESCR) (1966): art. 7(a)(i), art. 7(b), art. 8(1)(a), art. 12(1); International Covenant on Civil and Political Rights (ICCPR) (1966): art. $8(1), 8(3)(a)$, art. 22(1).

9 The terms 'investigative' and 'protective' powers are used interchangeably throughout this article.
} 
promotional and protective powers" (Murray 2007: 201) to provide them with flexibility in the means to achieve their objectives. I argue that the combination of strong promotional and investigative powers applicable to both state and non-state actors significantly enhances the capability of NHRIs to make an effective contribution to the prevention and protection of human rights by business firms.

Promotional powers typically comprize the power to provide education and training for key actors, such as police and other officials, to educate the wider public about their rights safeguards but also to propose policy changes and new laws to the government in order to end or prevent rights abuse and enhance compliance with national or international standards. Through promotional and advocacy work, NHRIs may be able to "draw extensive publicity to human rights concerns" and get these "onto the national agenda" (Linos and Pegram 2017: 680, 685). If their promotional powers extend to both state and non-state actors, NHRIs can play an important role "in driving positive industry practice and also generating rights respecting cultural change within the private sector" (McGrath 2019: 81) through persuasion and socialization. For instance, the activities of the Danish Institute for Human Rights are considered hugely influential across national boundaries in building both NHRI and private sector capacity to address corporate human rights abuse by providing training and guidance, and by conducting human rights impact assessments for multinational corporations such as Nestlé, Norsk Hydro, and Total (Haász 2013: 181; see DIHR 2013; 2017; 2019). Moreover, many NHRIs have contributed to the development and implementation of National Action Plans on Business and Human Rights (NAPs) through advocacy work, advice and National Baseline Assessments (e.g., the NHRIs of Germany, South Africa, and Zambia; see McGrath 2019: 81-82).

Yet promotional powers alone are unlikely to bring about sustainable change in hostile environments, when there are weak accountability mechanisms in place or where actors are reluctant to cooperate with NHRIs. Scholarship on corporate social responsibility (CSR) and on business and human rights suggests that business firms are highly strategic and selective in the form and extent of their commitment to CSR norms (Perez et al. 2019; LeBaron et al. 2021) and that they are especially reluctant to accept broad responsibility for the realization of human rights in their operation, as Favotto and Kollman (2021: 25; this issue) demonstrate in a study of the 50 largest British TNCs: "By refraining from 'showing' their human rights impacts and future commitments, firms actively resist the scrutiny NGOs, international organizations and actors populating the CSR field demand, as well as the accountability practices promoted [by the UN Guiding Principles on Business and Human Rights]." According to Favotto and Kollman, a major reason for this resistance is the difficulty to formulate a positive business case for greater human rights compliance, which results from the underlying tension between the different logics of corporate profit-seeking and human rights: "Profit-seeking pursues the seeker's own economic welfare," whereas the idea of human rights is "a moral interest in the welfare of others" (Gregg 2021: 68, this issue). Scholars thus argue for external checks and more stringent legislation which "would likely do more to change corporate culture and increase corporate monitoring of their supply chains" (Favotto and Kollman 2021: 24; see also Schilling-Vacaflor 2021, both in this issue) than voluntary commitments and promotional efforts by state and civil society organizations alone. 
It is therefore desirable that NHRIs are vested not only with promotional powers but also with strong investigative powers extending to the private sector, so that they are able to pressurize uncooperative perpetrators, including business firms, into collaboration and (eventually) into human rights compliance. Indeed, NHRI scholarship suggests that national institutions with strong investigative powers are generally more effective than those without them (Linos and Pegram 2017; Smith 2006: 917; Kumar 2003: 280). Investigative (or protection) powers include the capability to launch public inquiries and investigations into specific or systemic rights issues, to receive and resolve complaints, to make legal interventions in court cases or bring a case in its own right, to subpoena evidence and to issue and enforce compliance orders or recommendations. In a seminal study combining comprehensive quantitative and qualitative data from NHRIs across the globe, Linos and Pegram (2017: 680) have demonstrated that "one institutional safeguard above all, the power to initiate, execute, and complete investigations on receipt of complaints, stands out as particularly important in enabling NHRI effectiveness." This positive influence applies to NHRIs in developed democracies, as well as to those in developing and authoritarian settings with weak rule of law (Linos and Pegram 2017: 684). The capability to investigate complaints generates a number of direct and indirect positive effects: In the short term, it provides justice and (ideally) remedies to individuals who fell victim to human rights abuse. In the longer term, it helps NHRIs build credibility and public legitimacy which raises hurdles for political interventions and budget cuts by the government (Linos and Pegram 2017: 633, 684).

The ability to deploy both promotional and investigative powers in relation to state and non-state actors allows NHRIs to build up credible normative pressure visá-vis duty bearers and potential perpetrators by making them aware of their human rights responsibilities and obligations, advising them on how to identify and mitigate human rights risks in their operation and, if necessary, by launching inquiries or legal proceedings if the human rights risks or violations continue to persist and the NHRI's recommendations are being ignored. While a broad statutory mandate extending the NHRI's jurisdiction to the private sector constitutes a necessary structural condition, the sine qua non, for effective NHRI engagement with corporate human rights abuse, the ability to deploy a combination of promotional and investigative powers constitutes a second essential feature, as it represents the most promising route to bring about lasting behavioral change in different settings.

\section{NHRIs and Business in the Global Governance of Human Rights}

Before I analyze the extent to which the mandates and powers of NHRIs meet these conditions in practice, the following section examines the role envisaged for NHRIs in business and human rights regulation by the two most important international instruments for the governance of NHRIs and of business and human rights, respectively: the Paris Principles and the UN Guiding Principles. Although both instruments constitute non-binding, international soft law tools, they influence the legitimacy and operation of NHRIs in the field of business and human rights, in different ways. The Paris Principles are widely accepted to constitute the key international 
standard for the establishment and operation of NHRIs. Since their endorsement by the UN Commission for Human Rights and the UN General Assembly in 1993, they have not only shaped the design and structure of numerous national institutions around the world, but they continue to influence the mandates and competences of NHRIs as the benchmark of their transnational peer review and accreditation process. The UN Guiding Principles, on the other hand, constitute the most authoritative standards for the human rights duties or responsibilities of states and corporations adopted at the UN level and, as such, they shape the expectations about (and thereby generate acceptance of) the legitimate roles and contributions of relevant actors in the field of business and human rights, including NHRIs.

\section{The Paris Principles' Silence on Corporate Human Rights Abuse}

Developed by NHRI representatives in 1991 as minimum standards for the establishment of new institutions and for the operation of existing ones, the Paris Principles ("Principles Relating to the Status of National Institutions") ${ }^{10}$ quickly evolved as the key international norm governing the mandate, structure, and status of NHRIs. Following their endorsement in 1993 by the UN Commission for Human Rights and the UN General Assembly, the Paris Principles served as a design template for the creation of numerous national institutions around the world (Linos and Pegram 2016b: 1133). They also constitute the benchmark for NHRIs' international recognition and the granting of access and speaking rights at UN committees (Sidoti 2012: 96) based on their periodic review by the Sub-Committee on Accreditation (SCA) of the Global Alliance of NHRIs (GANHRI), the transnational network for the governance of NHRIs. ${ }^{11}$ The Paris Principles require NHRIs to have "broad constitutional and/or legislative mandates that cover all human rights; independence; an array of express human rights promotion and protection responsibilities; a pluralist representation; adequate funding; and responsibilities to cooperate, consult and interact with UN bodies, regional organizations, other NHRIs, other statutory bodies responsible for human rights promotion and protection, and human rights NGOs." (Reif 2017: 616)

Yet, it is evident that the Paris Principles do not explicitly require NHRIs to engage with human rights violations by non-state actors (Brodie 2012: 250). As Cantú Rivera (2020: 497, 498) notes, the Principles "do not explicitly refer to an [NHRI's] advisory role for actors other than the state," and they "do not contain a specific mandate" to redress cases of corporate human rights abuse. In fact, the Paris Principles "are silent on whether a NHRI must or should have jurisdiction over the private sector," as Reif (2017: 617) points out. However, scholars and practitioners have nonetheless tried to infer a business and human rights mandate from certain provisions of the Paris Principles. Meg Brodie's (2012: 250) interpretation has

\footnotetext{
10 Principles Relating to the Status of National Institutions (The Paris Principles), adopted by UNGA Resolution A/RES/48/134, 20 December 1993, art. 1, available at: https://www.un.org/ruleoflaw/files/ PRINCI 5.PDF (accessed 10 January 2021).

11 Formerly the International Coordinating Committee of NHRIs (ICC).
} 
been particularly influential in this regard, which acknowledges the Paris Principles' limitations but argues that they "nevertheless encourage NHRI action on businessrelated abuse." Brodie (2012: 250) extracts a private sector mandate primarily from the Principles' prescription to vest NHRIs with the "competence to promote and protect human rights," to give them "as broad a mandate as possible" and the responsibility to address "any situation of violation of human rights which it decides to take up". ${ }^{12}$ While it is possible to interpret these provisions in a way that allows, at least by implication, for NHRI engagement with corporate human rights abuse, they can hardly be read as specific forms of encouragement because this would imply much more explicit statements of an obligation or responsibility to address businessrelated rights abuse. The same critique applies to Brodie's interpretation of three other provisions, none of which contains explicit NHRI duties or responsibilities to promote and protect human rights in the private sector, or to directly engage with business firms in doing so. In fact, Brodie misses an important caveat when reading a business and human rights mandate into the Paris Principles' provision that an NHRI shall "freely consider any questions falling within its competence" and "hear any person and obtain any information and any documents necessary for assessing situations falling within its competence"13: The phrase "falling within its competence" in both provisions leaves the door wide open for restrictions of an NHRI's mandate and powers to the public sector under national law.

The fact that the Paris Principles do not contain a more explicit and comprehensive mandate for NHRI engagement with corporate human rights abuse is hardly surprising given the history of their creation. They were adopted at a time when the main focus of NHRI practice, and of the international human rights system as a whole, was on the protection against human rights violations committed by state actors (Deva 2011: 236). Apart from the nature of NHRIs as public bodies created and funded by the state, this is one of the main reasons for the imbalance in the Paris Principles between the strong emphasis placed on state actors, such as the government, parliament, judicial organizations and other authorities, and the relative neglect of non-state actors, whether from civil society or the private sector. Indeed, NHRI scholars have regularly criticized the Paris Principles for their state-centrism and legalism (e.g., Kumar 2003; Murray 2007).

Yet the Paris Principles pose another, more fundamental problem: an imbalance in the recommendation of powers. That is, they strongly recommend that NHRIs should be vested with promotional powers, such as the power to advise on legislative reform or to issue reports and recommendations to government and parliament, but they weakly recommend investigative powers. Most notably, they leave optional the power to receive complaints and to issue binding decisions, with subpoena powers specified only indirectly and within strict limits (Linos and Pegram 2016b: 1119). Because of this inherent imbalance, Richard Carver (2000: 2) criticized the Paris Principles as being "inadequate in a somewhat paradoxical way": They "lay down a maximum programme that is met by hardly any national institution in the

12 Paris Principles, paras. 1, 2 and 3(a)(ii).

13 Paris Principles, Methods of Operation, paras. (a) and (b). 
world [but] do not even take it as given that a national institution will deal with individual complaints, which most observers and practitioners in this field would probably regard as an essential characteristic." This paradox is the result of a mistake by the Paris Principles drafters who were unaware of the existence of human rights ombudsmen institutions in Latin America with strong complaints handling powers, as Linos and Pegram (2016a: 599) have demonstrated.

Despite that flaw, the Paris Principles' endorsement by various UN institutions and treaty bodies has triggered an unprecedented "norm cascade" in the establishment of new NHRIs around the world, with an increase from around 20 such institutions at the time of their adoption to 127 NHRIs registered with GANHRI in January 2021 (Linos and Pegram 2016b: 1110). ${ }^{14}$ However, the fact that the Paris Principles served as an international design template with an emphasis of promotive over investigative powers led to a situation in which "NHRIs set up after Paris were much more likely to include promotive functions, and much less likely to include protective functions, than NHRIs set up earlier" (Linos and Pegram 2017: 650). This means that the successful diffusion of the Paris Principles arguably facilitated the creation of NHRIs with an imbalance of powers and, thus, with limited capacity to effectively investigate and remedy cases of human rights abuse, including rights violations by corporate actors.

\section{The UN Guiding Principles: a Limited Role for NHRIs}

The UN Guiding Principles on Business and Human Rights ${ }^{15}$ were developed by the Special Representative of the UN Secretary-General (SRSG), John Ruggie, as the lynchpin of a new regulatory framework for corporate human rights accountability seeking to adjust the international human rights system to the "crisis in contemporary governance" caused by a largely unrestrained global market economy (Ruggie 2013: xxiii). The 31 Guiding Principles specify and operationalize three underlying pillars: the state duty to protect against human rights abuse by third parties including business corporations, the corporate responsibility to respect human rights, and the obligation of states to provide access to effective remedy for victims of business-related human rights abuse ("Protect, Respect and Remedy" framework, PRR). After their endorsement by the UN Human Rights Council in 2011, the UNGPs have evolved as the most authoritative standards for the human rights duties or responsibilities of states and corporations adopted at the UN level (De Schutter 2013) and

\footnotetext{
14 Of 127 registered NHRIs in January 2021, 84 have been accredited by GANHRI with A-status (in full compliance with the Paris Principles), 33 with B-status (partially compliant) and 10 are listed as C-no status (non-member and non-compliant). See GANHRI, Chart of the Status of National Institutions - Accreditation status as of 20 January 2021, available at: https://nhri.ohchr.org/EN/AboutUs/GANHR IAccreditation/Documents/Status\%20Accreditation\%20Chart\%20as\%20of\%2020\%2001\%202021.pdf (accessed 10 February 2021).

${ }^{15}$ United Nations Human Rights Office of the High Commissioner, Guiding Principles on Business and Human Rights: Implementing the United Nations "Protect, Respect and Remedy" Framework, HR/ PUB/11/04, New York and Geneva 2011, available at: https://www.ohchr.org/documents/publications/ guidingprinciplesbusinesshr_en.pdf (accessed 10 January 2021).
} 
have been integrated into policy frameworks and guidance by the European Union ${ }^{16}$ and the OECD. ${ }^{17}$ Moreover, a growing number of state governments has taken steps to implement them through National Action Plans on Business and Human Rights and legislation (Methven O'Brien et al. 2021, this issue).

Individually and through transnational networks, NHRIs quickly became involved in the consultations on the PRR framework and the Guiding Principles where they lobbied for inclusion of a prominent role for NHRIs (Brodie 2012; Haász 2013). When presenting the PRR framework to the UN in 2008, Ruggie envisaged NHRIs to "act as lynchpins within the wider system of grievance mechanisms" through the direct or indirect provision of remedies for victims of corporate human rights abuses. ${ }^{18}$ According to Haász (2013: 174), it was "challenging" for NHRIs in the consultations "to prove that the role of NHRIs should not be limited to the implementation of the third pillar of the framework," especially in light of the fact that "many NHRIs do not have an appropriate complaint handling function." Although NHRI advocates eventually persuaded Ruggie to include NHRIs in the final version of the commentary to the UNGPs under all three pillars (Methven O'Brien and Ford 2019: 221), it maintained its original emphasis of national institutions as remedy mechanisms.

The first of three substantive references to NHRIs is to be found in the commentary to Principle 3 of the state duty to protect human rights: "National human rights institutions that comply with the Paris Principles have an important role to play in helping States identify whether relevant laws are aligned with their human rights obligations and are being effectively enforced, and in providing guidance on human rights also to business enterprises and other non-State actors." 19 This commentary refers to the advisory and monitoring functions of NHRIs in relation to the state duty to protect from human rights abuse which includes the duty to protect from rights abuses by private actors. While it highlights the promotional function of NHRIs in relation to corporate actors, the commentary does not envisage national institutions to take on an active monitoring role in relation to business enterprises.

The commentary to Guiding Principle 23 relates to the corporate responsibility to respect human rights and contains the second substantive NHRI reference. It suggests that, when assessing the human rights risks in complex and difficult operating environments, such as conflict-affected areas, business enterprises "will often be well advised [...] to consult externally with credible, independent experts, including from Governments, civil society, national human rights institutions, and relevant

\footnotetext{
16 See European Commission: Communication from the Commission to the European Parliament, the Council, the European Economic and Social Committee and the Committee of the Regions: A renewed EU strategy 2011-14 for Corporate Social Responsibility, COM/2011/0681 final, 25 October 2011, available at: https://eur-lex.europa.eu/legal-content/EN/TXT/PDF/?uri=CELEX:52011DC0681\&qid=16167 $81448617 \&$ from $=\mathrm{EN}$ (accessed 10 January 2021).

17 OECD Guidelines for Multinational Enterprises, 2011 edition, section IV "Human Rights", available at: https://www.oecd.org/daf/inv/mne/48004323.pdf (accessed 10 January 2021).

18 UNHRC A/HRC/8/5, 7 April 2008, para. 97.

19 UNGPs, Pillar 1, p. 6.
} 
multi-stakeholder initiatives. ${ }^{20}$ This is clearly the weakest reference to NHRIs in the UNGPs' commentary in so far as it envisages them to play a passive, reactive role as potential advisers if companies wish to consult them, rather than suggesting a more proactive role in promoting and monitoring the implementation of the corporate responsibility to respect human rights.

The strongest reference to NHRIs is found under pillar three, in the commentary to Guiding Principle 27 which prescribes that "States should provide effective and appropriate non-judicial grievance mechanisms [...] for the remedy of businessrelated human rights abuse". The commentary specifies that "National human rights institutions have a particularly important role to play in this regard." ${ }^{21}$ This emphasis of the role of national institutions as state-based, non-judicial remedy mechanisms for corporate human rights abuse is not only in tension with the NHRI functions emphasized by the Paris Principles, but also with the limitations of many NHRIs' remedial competences in practice, as I will show in the following section. While the commentary to GP 27 entails a weak suggestion to create new non-judicial mechanisms or expand the mandates of existing ones to fill gaps in the provision of remedy for corporate human rights abuses, ${ }^{22}$ it does not explicitly recommend states to create new national institutions in line with the Paris Principles or to vest existing ones with a comprehensive mandate and adequate powers to act as effective non-judicial grievance mechanisms, for instance, through an express power to handle complaints, launch investigations, or initiate court proceedings.

The imbalanced and overall limited role for NHRIs envisaged by the UNGPs has led scholars to criticize Ruggie for failing "to include clearer, more comprehensive statements about the contribution NHRIs can make to the operationalisation of the [PRR] Framework," especially under pillar one and two, which "would have assisted NHRIs by preparing state and business actors to accept the inevitable linkages that will occur" (Brodie 2012: 257-258). The definition of a more balanced and comprehensive role for NHRIs under all three pillars would have also added to the effectiveness of the UNGPs, especially of the corporate responsibility to respect human rights, which is generally framed in non-authoritative and ambiguous terms and, according to critics, "unlikely to provoke a normative response" (Nolan 2013: 159). Although the Guiding Principles represent non-binding, non-enforceable standards of international soft law, the explicit recommendation to establish or designate NHRIs as monitoring and/or implementation mechanisms under all pillars would have added an "element of bindingness" that makes soft law more effective (Nolan 2013: 157). The failure to do so is also a missed opportunity to encourage national governments to enhance the mandates, powers, and resources of NHRIs, thereby enabling them to tackle corporate human rights abuse more effectively. As a result, the UNGPs provide NHRIs with relatively weak legitimacy to engage in the regulation of business and human rights and, especially, to hold corporate actors directly accountable for human rights abuses.

$\begin{array}{ll}{ }^{20} & \text { UNGPs, p. } 26 . \\ { }^{21} & \text { UNGPs, p. } 30 . \\ { }^{22} & \text { UNGPs, p. } 30 .\end{array}$ 


\section{Structural Limitations and How to Overcome Them}

The analysis of the Paris Principles and the UNGPs revealed a structural mismatch between the two most important international governance instruments for NHRIs and for human rights and business, respectively, regarding the legitimacy they provide, the functions they emphasize, and the expectations they raise, for NHRIs tackling corporate human rights abuse. The Paris Principles focus primarily on NHRIs' relationship with state actors and are silent on business-related rights abuse, thus prescribing only an implicit and relatively weak mandate for activities in this area. They strongly recommend inclusion of promotional powers while de-emphasizing investigative powers and leaving complaints handling powers optional. The UNGPs, on the other hand, refer to NHRIs in the commentary under all three pillars but do not envisage NHRIs to take on a proactive role as regulatory bodies monitoring the local implementation of the corporate responsibility to respect human rights. Ironically, the most substantive reference to NHRIs envisages them to function as nonjudicial grievance mechanisms, expecting NHRIs to have remedial powers that are only weakly recommended by the Paris Principles and, therefore, much less common among national institutions created after 1991 (see Linos and Pegram 2017: 650 , and the discussion in this article on p. 12).

The following section examines the available data from surveys and reports on the business and human rights mandates and competences of NHRIs, highlighting the structural limitations of the jurisdiction and complaints handling powers of many national institutions. To overcome these limitations, I propose a moderate reform of the Paris Principles to provide NHRIs with more robust international legitimacy and pressurize governments into enhancing their mandates and powers.

\section{Structural Gaps in NHRI Mandates and Powers}

Prior to the development of the "Protect, Respect and Remedy," framework, only a limited number of NHRIs have had experience with the promotion and protection of human rights in the corporate sector. ${ }^{23}$ The mandate of the SRSG functioned as a catalyst for NHRI networks and advocates to advance business and human rights as a strategic priority and to build up NHRI capacity around the globe. To that end, the International Coordinating Committee of NHRIs established a permanent working group on business and human rights in 2009 which facilitated NHRI engagement with UN institutions and mechanisms on business and human rights issues, including the SRSG, and encouraged NHRIs to address business-related human rights abuse in their work, most notably, through the Edinburgh Declaration of 2010. Adopted by the ICC at a thematic conference on business and human rights

\footnotetext{
23 The NHRIs of New Zealand, Kenya and Ghana are frequently mentioned as pioneers in this area, due to their public inquiries into the accessibility of public land transport for people with disabilities (2003), into the human rights impact of salt manufacturing companies (2005), and into the human rights of people living in mining communities (2006), respectively (Cantú Rivera 2020: 505; Haász 2013: 180; Brodie 2012: 266-269).
} 
in Edinburgh, the Declaration endorsed Ruggie's PRR framework and highlighted a range of NHRI activities for its operationalization, marking a shift from the prevailing tendency of NHRIs to focus on state violations (Brodie 2012: 255). As a result of the combined efforts by the ICC, various regional NHRI networks, as well as by individual institutions (including the Asia Pacific Forum, the Network of African NHRIs, and the Danish Institute for Human Rights), business and human rights issues have come to feature much more prominently in the strategic action plans of many NHRIs, and an increasing number of them is addressing corporate rights abuses on a regular basis.

Yet, summaries of good practice in the area of business and human rights also show that NHRI engagement is often confined to promotional or monitoring activities which provide access to effective remedy only indirectly. ${ }^{24}$ Moreover, there is evidence indicating that, despite a general increase in the awareness and activities in relation to business and human rights issues, many NHRIs are structurally inhibited in their ability to address corporate human rights abuse. Although there is relatively little robust and comprehensive data available on NHRI practice in the area of business and human rights, existing surveys and reports suggest that, apart from capacity and funding issues, limitations of their legal mandates and statutory powers pose the most significant challenge for more effective engagement with corporate rights abuse.

In their analysis of a UN survey from 2019 on the role of NHRIs in facilitating access to effective remedy in relation to business and human rights, experts of the Danish Institute for Human Rights found that the "mandate of some NHRIs explicitly prevents jurisdiction on business-related issues" (Götzmann and Lorion 2020: part 1, p. 10). Moreover, some NHRIs "argued that the lack of an explicit mandate to monitor the activities of businesses makes it difficult to protect against business-related abuses and seek remedy for them" (Götzmann and Lorion 2020: part 1, p. 10). A closer look at the survey responses reveals that a majority of 21 out of 33 responding institutions either identified limitations of their mandates as the most critical challenge for facilitating access to effective remedy in corporate rights abuses and/or recommended an extension of their mandates, often both. Most institutions suggested to include an explicit business and human rights mandate, to be vested with complaints handling powers and/or with quasi-judicial powers to issue and enforce legally binding decisions against corporate actors (Götzmann and Lorion 2020: annexes, table 1, pp. 12-26). With respect to NHRIs on the African continent, a NANHRI mapping survey of business and human rights work and competences showed that a total of 18 NHRIs (out of 32 responding institutions) indicated requiring support to have their legal mandates changed or amended, compared with 13 NHRIs indicating no need for amendment (NANHRI 2013: 60-61). ${ }^{25}$

\footnotetext{
${ }^{24}$ E.g., see the summary in Haász 2013: 179-183, and the 14 NHRI case studies on business and human rights engagement published by the Danish Institute for Human Rights on 15 January 2020, available at: https://www.humanrights.dk/publications/exploring-how-nhris-around-world-engage-business-humanrights (accessed 10 January 2021).

25 Among these 18 institutions, six NHRIs with A-status and ten NHRIs with B- and C-status indicated requiring "support to have [their] legal mandate changed or amended" to a "high extent" or "to some extent," plus two A-status NHRIs to a "limited extent." Nine A-status institutions and four B- and C-sta-
} 
Another indicator for deficient NHRI mandates can be found in the fact that GANHRI's Sub-Committee on Accreditation (SCA) has reprimanded nine NHRIs for lacking full jurisdiction over both the public and the private sectors. While this number may appear to be rather low, the SCA did not scrutinize NHRI mandates for jurisdiction over the private sector very regularly up until $2019 .{ }^{26}$ In light of the survey results cited above, it is likely that the actual number of NHRIs lacking full jurisdiction over the public and private sectors is significantly higher, and that future accreditation reports will bring this to light should the SCA continue to apply its current approach. In fact, the SCA adjusted its review criteria ("General Observations") in 2013 demanding as a new, essential requirement for Paris Principles compliance that the mandate of NHRIs "extends to the acts and omissions of both the public and private sectors." ${ }^{27}$ The revised criteria also recommended that NHRIs with complaints handling powers should have the "ability to receive complaints against both public and private bodies in its jurisdiction," although this feature was left optional. ${ }^{28}$ But as the SCA has so far not applied these criteria in a consistent manner nor as decisive requirements, they have not triggered widespread NHRI reforms by national governments. ${ }^{29}$ As long as the Paris Principles leave complaints handling powers optional, however, the SCA is technically inhibited from

\footnotetext{
Footnote 25 (continued)

tus NHRIs (13 in total) indicated no need for support and/or no need for an amendment (NANHRI 2013: 60-61).

${ }^{26}$ Four cases were reported in 2011 and 2012, five cases in 2019 and 2020. These include the NHRIs of Hungary (ICC, Report and Recommendations of the Sub-Committee on Accreditation, Geneva, May 2011); Austria (ICC, Report and Recommendations of the Sub-Committee on Accreditation, Geneva, May 2011); Bulgaria (ICC, Report and Recommendations of the Sub-Committee on Accreditation, Geneva, October 2011); Portugal (ICC, Report and Recommendations of the Sub-Committee on Accreditation, Geneva, November 2012); Armenia (ICC, Report and Recommendations of the Sub-Committee on Accreditation, Geneva, March 2019); Haiti (ICC, Report and Recommendations of the Sub-Committee on Accreditation, Geneva, March 2019); Honduras (ICC, Report and Recommendations of the Sub-Committee on Accreditation, Geneva, October 2019); Russian Federation (ICC, Report and Recommendations of the Sub-Committee on Accreditation, Geneva, October 2019); Albania (ICC, Report and Recommendations of the Sub-Committee on Accreditation, Geneva, December 2020). All SCA reports are availabe at: https://nhri.ohchr.org/EN/AboutUs/GANHRIAccreditation/Pages/SCA-Reports.aspx (accessed 10 January 2021).

27 General Observation 1.2 Human Rights Mandate, in: ICC, Report and Recommendations of the SubCommittee on Accreditation, Annex III-V, General Observations of the Sub-Committee on Accreditation. Geneva, May 2013, Annex V, p. 53.

28 General Observation 2.10 The quasi-judicial competency of National Human Rights Institutions (complaints-handling), in: ICC, Report and Recommendations of the Sub-Committee on Accreditation, Annex III-V, General Observations of the Sub-Committee on Accreditation. Geneva, May 2013, Annex V, p. 96.

29 Although the SCA has occasionally criticized NHRIs for lacking an explicit and comprehensive promotion and protection mandate extending to the private sector, it continued to re-accredit those institutions as fully Paris Principles-compliant (A-status), e.g., the NHRIs of Georgia, October 2018; Armenia, March 2019; Haiti, March 2019; and France, March 2019. The Bulgarian NHRI is one of the few documented exceptions where the government followed the SCA's recommendation and extended the institution's mandate to the private sector (ICC, Report and Recommendations of the Sub-Committee on Accreditation, Geneva, March 2019, p. 16).
} 
establishing strong investigative powers as a necessary requirement for full compliance with the Principles.

Moreover, according to UN survey data from 2008 and 2019, a considerable number of NHRIs has no complaints handling power in relation to corporate human rights abuses, and the vast majority of institutions that have such a power it is severely limited in its application to specific types of actors and/or specific rights. An oft-cited UN survey of NHRIs' ability to handle complaints with regard to private actors indicated that only nine out of 43 responding institutions were capable of investigating complaints in relation to any type of company and any human rights issue, and only seven of those were fully compliant with the Paris Principles (OHCHR 2008: 5). ${ }^{30}$ Fourteen NHRIs had no power to handle business-related complaints, while the remaining 20 institutions had such a power, but this was limited either to state-owned companies and business firms providing public services (11) and/or to specific rights issues, such as freedom from discrimination or labor rights (10). ${ }^{31}$ The 2019 survey by the UN Working Group on Business and Human Rights largely confirmed these results, despite a lower response rate. Of 33 responding institutions, 11 indicated to have no complaints handling power in relation to corporate rights abuses and 21 suggested to have such a power, although the nature and scope of this competence varied substantially (Götzmann and Lorion 2020: annexes, pp. 12-26). ${ }^{32}$

On the one hand, these numbers do not come as a surprise, given the Paris Principles' lack of an explicit NHRI mandate in relation to human rights abuses committed by non-state actors and the imbalance between strongly recommended promotional powers and weakly endorsed investigative powers. On the other hand, the fact that only relatively few NHRIs have a broad power to handle complaints of business-related rights abuses is "concerning", as Brodie (2012: 262) noted, because it means that "one of the key non-judicial mechanisms touted by the SRSG Guiding

\footnotetext{
30 The nine institutions were the NHRIs of: Egypt, Kenya, Mongolia, Philippines, Niger, Paraguay, Rwanda, Nigeria and Uzbekistan. The last two institutions were not accredited as compliant with the Paris Principles at the time. The NHRI of Jordan which is listed in the summary overview as the tenth institution with the ability to handle complaints in relation to any type of company and any human rights issue can, in fact, "only address complaints related to labour rights," according to the survey response, OHCHR 2008, p. 5, 17.

31 The complaints handling power of the NHRI of Mauritius is limited in both respects: It has the power to handle complaints regarding allegations of human rights abuse, sex discrimination and sexual abuse in relation to state-owned companies. In relation to other business firms, its complaint-handling power is limited to sex discrimination and sexual abuse, see OHCHR 2008, p. 20.

32 The NHRIs of the following countries indicated to have no legal mandate to handle complaints concerning business-related human rights abuses: Samoa, Albania, Azerbaijan, Denmark, Germany, Luxembourg, Poland, Serbia, Slovakia, Slovenia, and Spain. Some of those institutions indicated to have no complaints handling power at all, including Denmark, Germany, Luxembourg. While the authors of the survey report classify the NHRIs of Poland and Slovenia as institutions with a mandate to handle complaints regarding business-related rights abuses, the survey responses by these institutions state that they have no explicit mandate concerning alleged business-related rights abuses (Poland) and no mandate regarding the private sector (Slovenia), respectively, but that these institutions only interpret their mandates as broadly as to accept complaints against private actors providing public services, see Götzmann and Lorion 2020: annexes, p. 24, 26.
} 
Principles, can offer only limited protection via complaints mechanisms in OECD countries and their reach beyond that is not extensive."

Scholars have proposed to rectify the structural misalignment that underlies these mandate and power gaps by encouraging NHRIs to interpret their mandates and powers in a creative and expansive manner (Götzmann and Lorion 2020: part 1, p. 10; Reif 2017: 622; Brodie 2012: 270; Haász 2013: 184). Indeed, this is what many NHRIs have sought to do in practice, for instance, by engaging in business and human rights work without explicitly labeling it as such (Reif 2017: 630-631), by addressing business-related rights violations indirectly through enforcement of the state duty to protect (Cantú Rivera 2020: 499), or by engaging with business actors directly, despite the absence of an express mandate. ${ }^{33}$ However, this approach of 'creative self-empowerment' has clear limitations. With regard to promotional activities, it may be relatively uncontroversial for an NHRI lacking explicit jurisdiction over the private sector to provide advice and guidance to a business firm if this is based on mutual agreement. It is more difficult for a national institution to expand its protection functions to rights violations by non-state actors, let alone to claim investigative or enforcement powers without adequate statutory foundation, because "the complaints handling function of NHRIs tends to be one of the most prescriptive components of their establishing legislation" (Brodie 2012: 263). If it does, it is likely that targeted business firms will either refuse to cooperate or that they will challenge the NHRI's jurisdiction in court which may result in lengthy, costly, and damaging litigation. The objections reported by the Slovenian NHRI, and the legal challenges experienced by the NHRIs of Nigeria and the Philippines illustrate that these are not purely academic concerns. ${ }^{34}$ Creative self-empowerment by individual NHRIs raises expectations among stakeholders and within civil society that may be difficult to meet in practice. It thus presents a high-risk strategy that provides no incentive for governments to expand the formal mandates of NHRIs and potentially undermines their effectiveness in the longer term.

\footnotetext{
${ }^{33}$ Ghana's Commission on Human Rights and Administrative Justice (CHRAJ) has so far applied a particularly expansive interpretation of its mandate and powers, e.g., by interpreting its mandate to include not only complaint-based investigations but also own-motion investigations (Reif 2017: 629), and by visiting both public and private places of deprivation of liberty although it lacks an express legal power to inspect private detention facilities (ICC, Report and Recommendations of the Sub-Committee on Accreditation, Geneva, March 2019, p. 25).

${ }^{34}$ Although its mandate does not cover the private sector, the NHRI of Slovenia also handles complaints of alleged human rights abuses by private companies providing public goods and services. However, it reported in the 2019 survey that "this approach causes occasional objections" (Götzmann and Lorion 2020: part 1, p. 13). When the Philippines Commission on Human Rights launched a national inquiry into the impact of climate change on the human rights of the Filipino people and investigated the responsibility of 47 Carbon Majors, its requests and petitions were discarded by the companies many of which questioned the Commission's jurisdiction to handle the case (DIMR 2019: 31-33). The National Human Rights Commission of Nigeria was even forced to suspend an inquiry into the human rights impact of the activities of several oil companies operating in the Niger Delta after these companies challenged the Commission's power to hold the inquiry in court (DIMR 2019: 28-29).
} 


\section{Closing the Gaps Through a Reform of the Paris Principles}

In order to unlock the full potential of NHRIs for tackling business-related human rights abuses more effectively and put them in a position in which they are able to meet the expectations raised by stakeholders and the UNGPs, the governance instruments for the regulation of NHRIs and for corporate human rights accountability need to be aligned in a way that facilitates the closure of existing gaps in NHRIs' mandates and powers. The Paris Principles have proven a highly effective governance tool for the design of NHRIs around the world. As the basis of GANHRI's periodic peer review of NHRIs, they continue to be an influential steering mechanism for these bodies' effectiveness and independence as governments normally want to avoid a downgrading of their institutions by GANHRI (Linos and Pegram 2016a, b; 2017). Yet, in their current form, the Paris Principles act as a brake on the ability of NHRIs to tackle corporate human rights abuse more effectively because they do not prescribe a strong, explicit mandate to address human rights violations by non-state actors, and-perhaps even more importantly - they do not require states to vest their NHRIs with strong investigative powers, especially with the power to investigate complaints. However, both of these features constitute essential structural conditions for effective NHRI engagement with business and human rights. A possible way to resolve this mismatch would be to adjust the Paris Principles, in the following three ways: ${ }^{35}$

First, the absence of a specification of human rights in the Paris Principles should be substituted with a provision defining the human rights expressed in the International Bill of Human Rights as the range of rights norms to be covered, as a minimum, by the mandate of a national institution. That minimum range would include the rights norms expressed in the Universal Declaration of Human Rights, the International Covenant on Civil and Political Rights, and the International Covenant on Economic, Social, and Cultural Rights. This would lend international legitimacy to NHRIs in their engagement not only with civil and political rights abuses but also with violations of economic, social, and cultural rights that play a particularly important role in the human rights impact of business actors.

Second, the Paris Principles should be amended to clarify that the mandate and the competences of NHRIs should extend to acts and omissions of both the public and private sectors. That way, what is currently the SCA's specific interpretation of the Paris Principles as implying a private sector mandate becomes an explicit instruction and a necessary requirement in GANHRI's accreditation process for full compliance.

Third, the Paris Principles should prescribe as an essential feature the responsibility to receive and investigate complaints and petitions brought by any individual or organization, in relation to any human rights issue falling within the institution's

\footnotetext{
35 Although I am aware that the Paris Principles suffer from other shortcomings that deserve attention and revision, especially the issue of independence and accountability safeguards, I limit my proposal to those provisions which are most relevant for improving NHRI effectiveness in relation to tackling business-related human rights abuses.
} 
mandate as set out above. This could be done by elevating and enhancing the Paris Principles' current provision of the power to handle complaints from a weakly recommended, optional feature to a compulsory function of the same status and importance as promotional functions.

Amending the Paris Principles in this way would bring a number of advantages. If consistently applied in GANHRI's peer review process as necessary requirements for full compliance (A-status), the revised provisions would increase the pressure on state governments to close gaps in the jurisdiction and powers of their NHRIs, thereby opening new possibilities for them to tackle corporate human rights abuses, and to do so more effectively. It would align the features and powers prescribed by the Paris Principles with the remedial functions envisaged for NHRIs by the UNGPs and various UN resolutions endorsing them, thereby contributing to the 'hardening' of the Guiding Principles' soft law provisions. Pushing for the harmonization of NHRIs' mandates and powers through an update of the Paris Principles may also enhance their ability in the longer term to cooperate across borders in the monitoring and investigation of the human rights impacts of transnationally operating business firms and in the provision of remedy for victims of corporate rights abuses. Moreover, revising the Paris Principles would also strengthen the position and capability of NHRIs to function as, or collaborate with, OECD National Contact Points, and to act as National Implementation Mechanisms of a potential Business and Human Rights Treaty, as envisaged by a Draft Optional Protocol published in 2018 (for a detailed discussion, see Cantú Rivera 2020 and Jägers 2020; for a detailed analysis of different options for a treaty, see Bernaz 2021, this issue).

Proposing a renegotiation of the Paris Principles is highly controversial among NHRI scholars and practitioners. Although many of them criticize the Paris Principles for a number of flaws and shortcomings (e.g., Kumar 2003; 2006; Murray 2007; Harvey and Spencer 2012), a reform is considered undesirable due to the perceived risk of co-option by states and the dilution of key provisions (Mertus 2012: 89; Linos and Pegram 2017: 685, 687). However, this is a risk of any political (re-) negotiation and no specific argument against reforming the Paris Principles. Compared with the complex multi-stakeholder negotiations of the UNGPs, as well as to those of the Draft Business and Human Rights Treaty (see Hamm 2021, this issue), the risk of co-option and failure of a modest reform of the Paris Principles under GANHRI's leadership appears to be rather limited, especially if the terms of reference for a re-negotiation would require any changes to be aimed at extending, not restricting, the mandate and powers of NHRIs. To further minimize the risk of state capture and dilution of existing standards, it may be an alternative option to leave the Paris Principles unchanged but to adopt a supplementary declaration which would prescribe the extension of NHRIs' mandates and competences in the ways set out above.

Since the adoption of the Paris Principles 30 years ago, there have never been more GANHRI-accredited NHRIs fulfilling basic standards of institutional independence and effectiveness, and they have arguably never been better organized and positioned to steer a reform process of their most fundamental international guidelines. In fact, the ground for such an endeavor has already been prepared by the resolutions and recommendations of various UN bodies that NHRI advocates can 
draw on. The UN Committee on the Rights of the Child demanded as early as 2002 that all NHRIs should be empowered to investigate complaints, including those submitted by and on behalf of children, and to promote and protect the rights of children in both the public and private sectors. ${ }^{36}$ The UN General Assembly repeatedly encouraged governments to give NHRIs an investigative role, and the UN Working Group on Business and Human Rights recommended to provide NHRIs with the mandate and resources to handle complaints regarding business-related human rights abuses. ${ }^{37}$ Moreover, the current US administration's plans to strengthen the role of UN bodies and mechanisms and the political appetite of the EU Commission to introduce ambitious corporate human rights due diligence standards suggest that there is a rare window of opportunity to realize a progressive reform of the international guidelines for NHRIs, with a rather limited risk of opposition or co-option. ${ }^{38}$ If NHRIs are to tackle the negative human rights impacts of a globalized market economy more effectively, an update of the Paris Principles is long overdue.

\section{Conclusion}

After the adoption of the UNGPs, Haász (2013: 184) argued that the business and human rights field "now has its norms and implementation tools;" what is needed "is a better understanding of these tools and a stronger commitment to implementing the existing standards." By contrast, this article showed the gaps and inadequacies of the existing framework for the transnational governance of business and human rights with regard to the role of NHRIs. In particular, it revealed a structural mismatch between the Paris Principles and the Guiding Principles, as well as between the expected contribution of NHRIs to the prevention and remedy of corporate human rights abuse and the limitations of their mandates and powers in practice. Only a limited number of NHRIs has full jurisdiction over both the public and private sectors and is vested with strong promotional and investigative powers applicable to state and non-state actors, which are essential structural conditions for tackling business-related rights abuses effectively in different settings and in an enduring manner. Yet, as Cantú Rivera (2020: 512) has pointed out, it is "Only through cooperative and coercive measures - that is, through a 'smart mix' of measures-[that] hope for remedy [will] transform into a reality for victims."

\footnotetext{
${ }^{36}$ Committee on the Rights of the Child, CRC/GC/2002/2, 15 November 2002, paras. 9, 13; see also CRC/C/GC/16, 17 April 2013, paras. 30, 75.

37 UNGA A/RES/63/172, 18 December 2008, para. 11; A/RES/70/163, 10 February 2016, para. 20; UN Working Group on Business and Human Rights, Guidance on National Action Plans on Business and Human Rights (Version 1.0, December 2014), p. 30.

38 For the EU's plans and options, see: European Union Directorate-General for External Policies, Policy Department (2020) Human Rights Due Diligence Legislation - Options for the EU. Briefings. EP/EXPO/ DROI/FWC/2019-01/LOT6/1/C/05. Available at: https://www.europarl.europa.eu/RegData/etudes/BRIE/ 2020/603495/EXPO_BRI\%282020\%29603495_EN.pdf (Accessed 10 January 2021). Also, neither the United States, China, nor Brazil currently have an NHRI registered with GANHRI which makes opposition from their governments against a reform of the Paris Principles less likely.
} 
A moderate reform of the Paris Principles along the lines proposed in this article would likely enhance the effectiveness of NHRIs in the regulation of business and human rights. As decisive compliance criteria of GANHRI's accreditation process, the refined Paris Principles would increase the pressure on governments to close gaps in the mandates and powers of their national institutions with regard to the private sector. They would open new opportunities for NHRIs to engage with state and non-state actors, with a broader range of rights issues (including socio-economic rights), and in activities many national institutions are currently unable to pursue, including handling complaints and launching investigations. Last, but not least, they would enhance the capabilities of NHRIs to implement the UNGPs and to act as effective National Implementation Mechanisms of a potential Business and Human Rights treaty in the future.

Acknowledgements For helpful comments on earlier versions of this article, I would like to thank the two anonymous reviewers, Elisabeth Badenhoop, Nadia Bernaz, Petra Dobner, Alvise Favotto, Jasper Finkeldey, Torben Fischer, Benjamin Gregg, Kelly Kollman, Markus Krajewski, Andrej Lang, Yingru Li, John McKernan, Janne Mende, Claire Methven O'Brien and all participants of the conference "The UN Guiding Principles and the Future of Business and Human Rights Regulation" which took place in February 2020 at Martin Luther University Halle-Wittenberg. I would also like to thank the staff and research fellows of the Lichtenberg Kolleg at Georg August University Göttingen, in particular the "Human Rights" research group directed by Matthias Koenig, for their hospitality and support during my research visit in January and February 2020 where the groundwork for this article was laid.

Funding Open Access funding for this article is provided by Projekt DEAL.

\section{Declarations}

Conflict of Interest No potential conflict of interest was reported by the author.

Open Access This article is licensed under a Creative Commons Attribution 4.0 International License, which permits use, sharing, adaptation, distribution and reproduction in any medium or format, as long as you give appropriate credit to the original author(s) and the source, provide a link to the Creative Commons licence, and indicate if changes were made. The images or other third party material in this article are included in the article's Creative Commons licence, unless indicated otherwise in a credit line to the material. If material is not included in the article's Creative Commons licence and your intended use is not permitted by statutory regulation or exceeds the permitted use, you will need to obtain permission directly from the copyright holder. To view a copy of this licence, visit http://creativecommons.org/licen ses/by/4.0/.

\section{References}

Bernaz N (2017) Business and human rights. History, law and policy: bridging the accountability gap. Routledge, Abingdon.

Bernaz N (2021) Conceptualizing corporate accountability in international law: models for a business and human rights treaty. Human Rights Review 22(1), 45-64. https://doi.org/https://doi.org/10.1007/ s12142-020-00606-w

Brodie M (2012) Pushing the boundaries: the role of national human rights institutions in operationalising the 'Protect, Respect and Remedy' framework. In: Mares R (ed.) The UN Guiding Principles on Business and Human Rights: foundations and implementation. Brill, Leiden, pp. 245-272. 
Brodie M (2015) Uncomfortable truths: protecting the independence of national human rights institutions to inquire. University of New South Wales Law Journal 38(3): 1215-1260.

Cantú Rivera H (2020) National human rights institutions and their (extended) role in the business and human rights field. In: Deva S, Birchall D (eds.) Research handbook on human rights and business. Edward Elgar, Cheltenham, pp. 492-512.

Cardenas S (2014) Chains of justice: the global rise of state institutions for human rights. University of Pennsylvania Press, Philadelphia.

Carver R (2000) Performance and legitimacy: national human rights institutions. ICHRP, Versoix.

Danish Institute for Human Rights (DIHR) (2013) Talking the human rights walk: Nestlé's experience assessing human rights impacts in its business activities. DIHR, Copenhagen. https://www.human rights.dk/sites/humanrights.dk/files/media/migrated/nestle-hria-white-paper_0.pdf (Accessed 10 January 2021).

Danish Institute for Human Rights (DIHR) (2017) Hydro human rights impact mapping. DIHR, Copenhagen. https://www.humanrights.dk/sites/humanrights.dk/files/media/migrated/hydro_report_janua ry_2017.pdf (Accessed 10 January 2021).

Danish Institute for Human Rights (DIHR) (2019) Papua LNG human rights impact assessment: focus on gender, security and conflict. DIHR, Copenhagen. https://www.humanrights.dk/sites/humanrights. dk/files/media/document/ \%2019_02922-15\%20papua_lng_hria_summary_report_final_feb2019\% 20-\%20fd\%20461989_1_1.PDF (Accessed 10 January 2021).

De Schutter O (2013) Foreword: beyond the Guiding Principles. In: Deva S, Bilchitz D (eds.) Human rights obligations of business: beyond the corporate responsibility to respect? Cambridge University Press, Cambridge, pp. xv-xxii.

Deutsches Institut für Menschenrechte (DIMR) (2019) Remedy in business and human rights cases: the role of national human rights institutions. DIMR, Berlin.

Deva S (2011) Corporate human rights abuses: what role for the national human rights institutions? In: Nasu H, Saul B (eds.) Human rights in the Asia-Pacific region: towards institution building. Routledge, Abingdon, pp. 234-248.

Deva S, Bilchitz D (eds.) (2013) Human rights obligations of business: beyond the corporate responsibility to respect? Cambridge University Press, Cambridge.

Favotto A, Kollman K (2021) When rights enter the CSR field: British firms' engagement with human rights and the UN Guiding Principles. Human Rights Review (2021), online first. https://doi.org/10. 1007/s12142-020-00614-w

Goodman R, Pegram T (2012) Introduction: national human rights institutions, state conformity, and social change. In: Goodman R, Pegram T (eds.) Human rights, state compliance, and social change: assessing national human rights institutions. Cambridge University Press, Cambridge, pp. 1-25.

Götzmann N, Lorion S (2020) National human rights institutions and access to remedy in business and human rights. Danish Institute for Human Rights, Copenhagen.

Gregg B (2021) Beyond due diligence: the human rights corporation. Human Rights Review 22(1): 65-89. https://doi.org/https://doi.org/10.1007/s12142-020-00605-X

Haász V (2013) The role of national human rights institutions in the implementation of the UN Guiding Principles. Human Rights Review 14(3): 165-187.

Hamm B (2021) The struggle for legitimacy in business and human rights regulation: a consideration of the processes leading to the UN Guiding Principles and an International Treaty. Human Rights Review (2021) online first. https://doi.org/10.1007/s12142-020-00612-y

Harvey C, Spencer S (2012) Advancing human rights and equality: assessing the role of commissions in the United Kingdom and Ireland. Fordham International Law Journal 35(2012): 1615-1689.

International Coordinating Committee of National Institutions for the Promotion and Protection of Human Rights (ICC) (2010) The Edinburgh Declaration. https://nhri.ohchr.org/EN/Themes/Busin essHR/DocumentsPage/Edinburgh_Declaration_ENG.pdf (Accessed 10 January 2021).

Jägers N (2020) National human rights institutions: the missing link in business and human rights governance? Vienna Journal on International Constitutional Law 14(3): 289-325.

Kumar CR (2003) National human rights institutions: good governance perspectives on institutionalization of human rights. American University International Law Review 19(2003): 259-300.

Kumar CR (2006) National human rights institutions and economic, social, and cultural rights: toward the institutionalization and developmentalization of human rights. Human Rights Quarterly 28(3): 755-779. 
LeBaron G, Edwards R, Hunt T, Sempéré C, Kyritsis P (2021) The ineffectiveness of CSR: understanding garment company commitments to living wages in global supply chains. New Political Economy, online first.

Linos K, Pegram T (2016a) The language of compromise in international agreements. International Organization 70 (Summer): 587-621.

Linos K, Pegram T (2016b) Architects of their own making: national human rights institutions and the United Nations. Human Rights Quarterly 38(4): 1109-1134.

Linos K, Pegram T (2017) What works in human rights institutions? The American Journal of International Law 111(3): 628-688.

Mares R (ed.) (2012) The UN Guiding Principles on Business and Human Rights: foundations and implementation. Brill, Leiden.

McGrath S (2019) National human rights institutions and business and human rights: challenges, opportunities and next steps. In: Mullen $\mathrm{M}$ et al. (eds.) Navigating a new era in business and human rights, pp. 80-89. https://article30.org/wp-content/uploads/2019/08/a_new_era.pdf (Accessed 10 January 2021).

Mertus JA (2009) Human rights matters: local politics and national human rights institutions. Stanford University Press, Stanford.

Mertus JA (2012) Evaluating NHRIs: considering structure, mandate, and impact. In: Goodman R, Pegram T (eds.) Human rights, state compliance, and social change: assessing national human rights institutions. Cambridge University Press, Cambridge, pp. 74-90.

Methven O'Brien C, Ferguson J, McVey M (2021) National Action Plans on business and human rights: an experimentalist governance analysis. Human Rights Review (2021), forthcoming.

Methven O'Brien C, Ford J (2019) Business and human rights: from domestic institutionalisation to transnational governance and back again. Nordic Journal of Human Rights 37(3): 216-233.

Murray R (2007) National human rights institutions: criteria and factors for assessing their effectiveness. Netherlands Quarterly of Human Rights 25(2): 189-220.

Network of African National Human Rights Institutions (NANHRI) (2013) Report of the NANHRI mapping survey on business and human rights. The Network of African National Human Rights Institutions, Nairobi.

Nolan J (2013) The corporate responsibility to respect human rights: soft law or not law? In: Deva S, Bilchitz D (eds.) Human rights obligations of business: beyond the corporate responsibility to respect? Cambridge University Press, Cambridge, pp. 138-161.

Office of the United Nations High Commissioner for Human Rights (OHCHR) (2008) Business and human rights: a survey of NHRI practices. July 2008, available at: https://media.business-human rights.org/media/documents/f0ecca4f3e6b9322160832e41578adf26d6db22a.doc (Accessed 10 January 2021).

Perez O, Cohen R, Schreiber N (2019) Governance through global networks and corporate signaling. Regulation \& Governance 13(4): 447-469.

Reif LC (2017) The UN Guiding Principles on Business and Human Rights and networked governance: improving the role of human rights ombudsman institutions as national remedies. Human Rights Law Review 17(4): 603-632.

Rodríguez-Garavito C (ed.) (2017) Business and human rights: beyond the end of the beginning. Cambridge University Press, Cambridge.

Rosenblum P (2012) Tainted origins and uncertain outcomes: evaluating NHRIs. In: Goodman R, Pegram $\mathrm{T}$ (eds.) Human rights, state compliance, and social change: assessing national human rights institutions. Cambridge University Press, Cambridge, pp. 297-323.

Ruggie JG (2013) Just business: multinational corporations and human rights. W. W. Norton, New York.

Schilling-Vacaflor A (2021) Putting the French duty of vigilance law in context: towards the corporate accountability for human rights violations in the Global South? Human Rights Review 22(1): 109127. https://doi.org/https://doi.org/10.1007/s12142-020-00607-9

Schuller C, Utlu D (2014) Transnational cooperation in business and human rights: a model for analysing and managing NHRI networks. German Institute for Human Rights, Berlin.

Sidoti C (2012) National human rights institutions and the international human rights system. In: Goodman R, Pegram T (eds.) Human rights, state compliance, and social change: assessing national human rights institutions. Cambridge University Press, Cambridge, pp. 93-123.

Smith A (2006) The unique position of national human rights institutions: a mixed blessing? Human Rights Quarterly 28(4): 904-946. 
Wolfsteller R (2017) The institutionalisation of human rights reconceived: the human rights state as a sociological 'ideal type'. The International Journal of Human Rights 21(3): 230-251.

Wolfsteller R (2020) Out of sync: The failed translation of international human rights in the creation of the UK Human Rights Act. Journal of Human Rights 19(3): 325-343.

Wolfsteller R, Gregg B (2017) A realistic utopia? Critical analyses of The Human Rights State in theory and deployment: guest editors' introduction. The International Journal of Human Rights 21(3): 219-229.

Publisher's Note Springer Nature remains neutral with regard to jurisdictional claims in published maps and institutional affiliations. 